Archived version from NCDOCKS Institutional Repository http://libres.uncg.edu/ir/asu/

\title{
Appalachľan
}

B O O N E, NORTH CAROLINA

\section{Economic Globalization and Bolivia's Regional Divide}

\author{
By: Kathleen Schroeder
}

\begin{abstract}
Bolivia provides an example of the immense complexity of local responses to globalization. This paper emphasizes the regional differences that influence how Bolivians react to economic globalization and in particular to the terms of sale of natural gas. Some high-land indigenous communities contest aspects of the neo-liberal global economy while many in the lowland mestizo class embrace opportunities that come from participation in the global economy. The election of Evo Morales in 2006 has brought many of these differences to the forefront because he has vowed to favor domestic consumption of natural gas over export and take seriously the state's responsibilities to the poor. Keywords: Bolivia, globalization, Evo Morales.
\end{abstract}

\section{Resumen}

El caso de Bolivia sirve como muestra de la inmensa complejidad que existe en las respu-estas locales a la globalización. Este trabajo se enfoca en las diferencias regionales que influyen en la reacción de los bolivianos a la globalización económica, especialmente con respecto a las condiciones para la venta del gas natural. Algunas comunidades indígenas de las tierras altas disputan ciertas características de la economía global neoliberal, mien-tras que muchos grupos de las tierras bajas, donde predomina la clase mestiza, están a favor de las oportunidades que surgen de la participación en la economía global. La elec-ción de Evo Morales en 2006 hace resaltar muchas de estas diferencias debido a su de-cisión de cumplir con las responsabilidades del estado hacía los pobres y su compromiso de promover el consumo doméstico, y no la exportación, del gas natural.

Kathleen Schroeder (2007) "Economic Globalization and Bolivia's Regional Divide" Journal of Latin American Geography Volume 6 Issue 2 pp. 99-120. Version of Record Available from (www.muse.jhu.edu) 


\section{Introduction}

In recent decades, Latin America has experienced a growing number of social and political movements with roots in indigenous communities from Chiapas, Mexico, to southern Chile (Delgado 1994, Langer 2003, Stephenson 2002, Yashar 1998). In Bolivia, indigenous peoples played a critical role in deposing President Gonzalo Sánchez de Lozada (widely known by his nickname Goni) in October of 2003, in part, because he supported a neoliberal plan to engage in the international sale of natural gas. In January of 2006, Bolivia's first indigenous president, Evo Morales, was sworn into office. On May $1^{\text {st }}$ of 2006, he acted on a campaign promise that supported the nationalization of the country's natural gas fields. Many Bolivia watchers saw the nationalization of the gas fields as an attack on previous administrations' neo-liberal agenda of economic globalization.

June Nash (2001), a leading scholar on Bolivia, turns her attention to Chiapas, 
Mexico in Mayan Visions: The Quest for Autonomy in an Age of Globalization. The insights she gains from her work in highland Chiapas contribute substantially to our understanding of the situation in contemporary Bolivia. In particular, Nash emphasizes a definition of globalization which stresses integration of the global economy and in particular, a shift from domestic production to export production. This model assumes a free and self-regulating market that operates outside the control of national and international regulatory agencies. This free and self-regulating market coexists with an economic and political model that sells off public enterprises and decreases government responsibility for the poor (Nash 2001, 3). Working in Bolivia, Gill (2000) has called the state's abdication of responsibility for welfare the "armed retreat of the Bolivian state."

Opposition to export promotion at the expense of domestic consumption in the gas industry was a key motivator of Evo Morales' supporters (Kohl and Farthing 2006). But a variety of complex issues helped bring Evo Morales into office. Indigenous resistance to globalization has captured headlines across the world and the election of Evo Morales has once again made Bolivia an international symbol of the anti-globalization movement. However, it is important to note that most indigenous Bolivians do not simply reject an abstract idea of "globalization." They reject a neo-liberal economic agenda which continues to privilege the elite. Indigenous Bolivians do not oppose engagement in the global economy. They oppose engagement that continues to disadvantage them.

In Bolivia, some indigenous communities have organized to resist aspects of the neo-liberal global economy while many within the mestizo class embrace the opportunities that come from participation in global markets. Geographically, the movement for indigenous nationalism is located most strongly on the Bolivian altiplano (high plateau), in the valley city of Cochabamba, and in the lowland coca-growing Chapare. The growing mestizo movement is strongly associated with the lowland city of Santa Cruz, to a lesser extent the city of Tarija, and the eastern flanks of the country. The eastern region of Bolivia is much more eager to embrace the neo-liberal agenda for economic globalization. The city of Santa Cruz is the center of the autonomy movement and home to people well prepared to profit from economic globalization. This case from Bolivia highlights the complexity of the globalization debate by examining two clearly defined and regionally based paths for the future of the country.

Bolivia has always been a multi-ethnic country with strong regional characteristics. Many scholars have examined the cultural and regional tensions at work in Bolivia especially those between highland and lowland Bolivians. Stearman (1985) focuses on the integration of highland Bolivians as they migrated to lowland cities such as Santa Cruz. Schroeder (1998) examines how former tin-miners from the highlands shifted occupations and adjusted to life in the lowland city of Tarija. A sophisticated analysis of Bolivia's regionalism by José Luis Roca (1999) explains the complicated geography of the country and provides insight into how distinct regional cultures impact Bolivia's political reality. In general, people of the highlands have strong ties to distinct indigenous groups (in particular Quechua and Aymara peoples), while those of the eastern lowlands have a stronger mestizo culture.

Keeling's 2004 discussion of globalization published in this journal frames this paper by providing a clear theoretical and practical analysis of the implications of globalization for Latin America. He differentiates among a variety of critical impacts that globalization is having in the region. Keeling calls for the use of the term "glocalization" to call attention to the local adaptations and implications of globalization. The case study I provide from Bolivia provides a "glocalized" analysis of the "growing polarization of society" and "conflicting socio-cultural identities" that Keeling identifies. The Bolivian case makes clear that local people are aware of the impacts of globalization and are 
struggling to control these processes. Bolivia also provides an example of the immense complexity of local responses to globalization. Some of this complexity has a regional pattern, as surely some parts of Bolivia are better situated to benefit from engagement in the global economy. However, many surprises and contradictions exist.

Based on the premise that neoliberal economic reforms will eventually benefit even the poorest of the poor, many Latin American economies (including Bolivia's) have withstood long periods of "adjustment" that have resulted in what Keeling describes as a growing (economic) polarization. I would add that, in the case of Bolivia at least, a regional polarization is also occurring. During the 1980s, Bolivia's state employees were one key target of reform measures. Displaced state employees (particularly tin miners from the state-owned mines in the highlands) have played important roles in an authentic Bolivian resistance to income inequality, which has recently contributed to the election of the populist indigenous president Evo Morales.

Bolivian socio-cultural identities are deeply complex and influenced from numerous sources. These too are spatially rooted. Much as Keeling describes, a part of the Bolivian population embraces an identity, "that is constructed by individual success, innovative entrepreneurialism, the conspicuous consumption of global products" (2004, 14) and the like. Another segment of the Bolivian population embraces its traditional roots and demands that the needs of poor not be ignored. As these factions of the Bolivian population collide, geographical patterns emerge, including a serious discussion over regional autonomy that is threatening to drive the country even further apart.

A growing body of evidence indicates a widening political and economic gulf between Bolivia's highlands and lowlands (Lowrey 2006). Bolivia seems on the verge of being torn apart by separate visions for its future. Indigenous groups in the highlands and mestizo groups in the lowlands both appeal to a strong sense of place-based identity as they apply pressure on the central government to further their separate and non-compatible political and economic agendas. In many ways, two Bolivias exist: one that is eager to embrace the global economy, and another Bolivia that honors the traditional Andean moral economies (Edelman 2005, Scott 1976).

This paper emphasizes the regional differences that are influencing how Bolivia reacts to economic globalization. It begins with a discussion of the rebirth of Aymara nationalism in Bolivia, within the context of how the struggle to preserve highland culture contributed to the political and economic agenda of Evo Morales' MAS Party and the eventual nationalization of the country's gas fields. Next, the paper focuses on the growing frustration of lowland mestizos. Many of the lowlanders, including mestizos but also some of the indigenous Guaraní population, want greater regional autonomy and more control over the export of the natural gas that is found in their region. An explanation of the 2003 ouster of President Gonzalo Sánchez de Lozada is offered, as the moment when long-simmering tensions between the two Bolivias exploded. Over two separate Presidential terms, Sánchez de Lozada represented the views of mestizo, neoliberal, pro-economic globalization, potentially gas-rich eastern Bolivia against the indigenous peoples of the highlands. The aftermath of the post-Goni era is examined by an analysis of regional patterns evident in the 2004 Gas Referendum and the Presidential Election of 2005. The article concludes with comments on the nationalization of the natural gas fields and the challenges ahead for President Morales.

\section{Economic Globalization in the Highlands}

Andean nationalism not only has deep roots, it has serious economic and political implications for the future of Bolivia. Resistance to economic globalization in the Andes is rooted in the fact that the global economy is doing very little to help rural indigenous 
people and may even be increasing their poverty. In some areas of Bolivia, there has been a measurable and substantial reduction in poverty during the decade after 1991 (INE 2001). However, reduction of poverty in Bolivia shows significant regional differences, with the eastern part of the country faring better than the highlands. In addition, urban areas have done better than rural zones. Areas that have seen increases in poverty from 1991 to 2001 are almost exclusively highland, rural and indigenous (Figure 1).

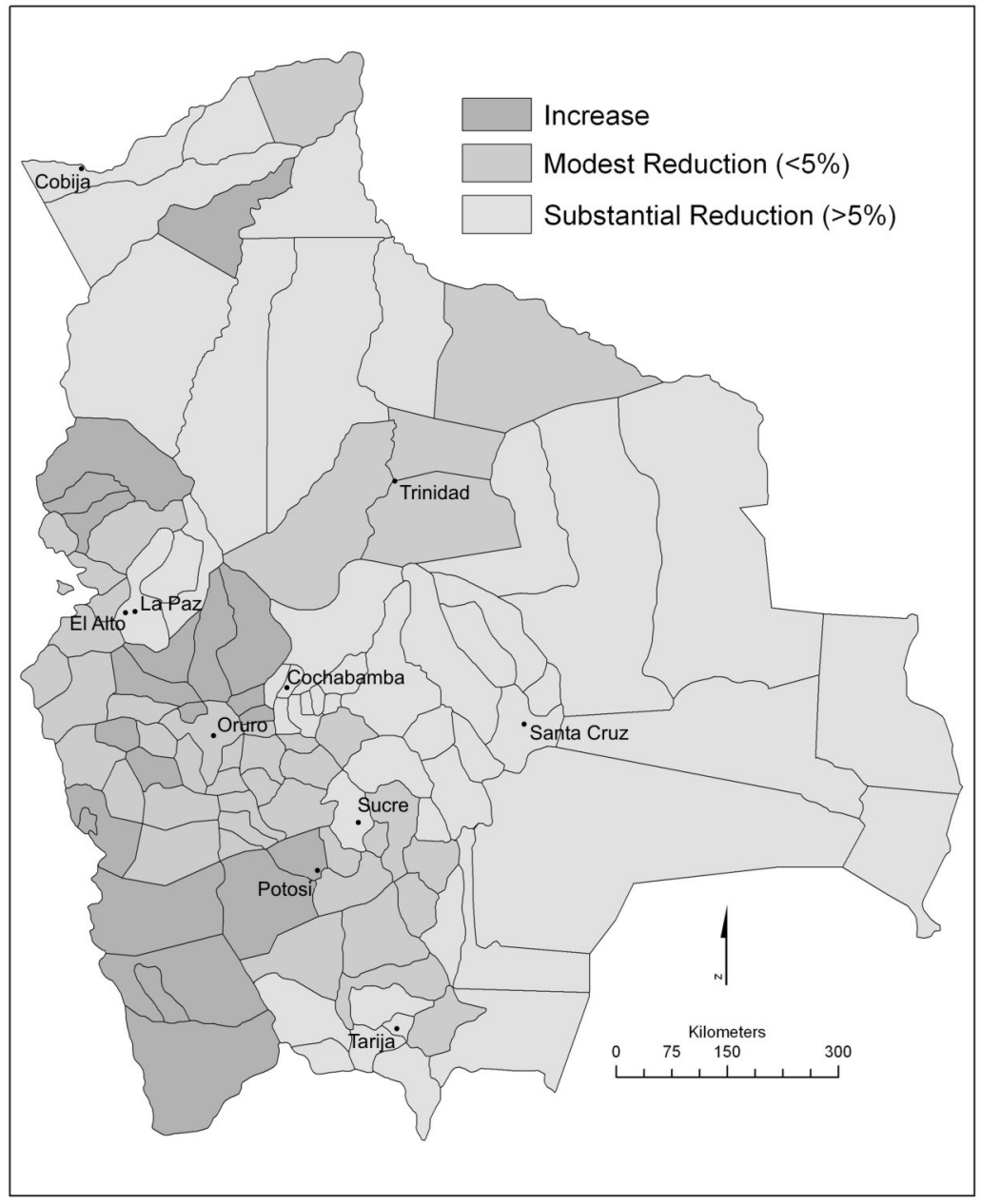

Figure 1. Change in Poverty 1991-2001. Source: INE 2001.

Looked at another way, Bolivians who consider themselves indigenous (especially in the rural highlands) are doing more poorly than those who consider themselves mestizo. Indigenous families have lower levels of material wealth, sanitation and housing quality than non-indigenous families (Liberato, Pomeroy and Fennell 2006). These tangible differences in people's quality of life have had a profound impact on the country. The rural highland population is fighting a real, and by all appearances, losing battle against 
poverty, while facing increasing pressures to engage in the global economic system.

\section{Katarismo on the Altiplano}

Indigenous movements in Bolivia are centered on the altiplano and in particular the cities of La Paz and El Alto. This region is home to several hundred thousand Aymara-speakers (Canessa 2000,120). Indigenous peoples in the highland city of El Alto have been particularly active in organizing against neoliberal economic policies (Gill 2000). Cochabamba, another city with strong indigenous political movements, is the home of tens of thousands of tin miners who were displaced during the economic crises of the 1980s and subsequent mine closures (Crabtree, Duff and Pearce 1987). Bolivian miners are a notoriously well-organized and a politically savvy group with strong Quechua roots (Dunkerley 1984, Nash 1979). Morales' first political experiences were working with coca-growers in the Chapare, a region near the city of Cochabamba that absorbed many of the displaced miners (Orozco Ramírez 2005).

A rebirth of indigenous nationalism, known as Katarismo, led by students, intellectuals, and peasants, began in the 1970s in La Paz to help preserve what was left of the traditional culture of the altiplano (Mallon 1992). This movement reclaimed Katari as a symbol to help reinvigorate indigenous culture. Interest in traditional languages such as Aymara and Quechua grew, as did appreciation for traditional music and craft production. The movement had a political wing, and many of Bolivia's indigenous leaders today took inspiration and gained political experience from the Kataristas of the 1970s (García Linera 2003).

Kataristas demand status equal to the dominant mestizo class. This counter-hegemonic movement took its inspiration and name from Julián Apaza, who later changed his name to Túpac Katari, the Aymara leader who launched an anti-colonial campaign on the high plains two hundred years before. Túpac Katari led both a military and a symbolic campaign against Spaniards and their culture. Among other cultural stances, the movement prohibited Andean people from practicing European customs such as speaking Spanish or eating European foods, such as wheat bread (Mallon 1992). Katari is most famous for his role in the siege of $\mathrm{La} \mathrm{Paz}$ in 1781. The siege clearly had racial implications, as Katari's intent was to rid the region of Europeans. Recent historical research on the siege of La Paz has characterized it as a race war (Thomson 2002, 185). The siege led to many deaths--most due to starvation as the city of La Paz ran out of food because it was cut off from agricultural areas for 109 consecutive days (Serulnikov 2003, 194).

In La Paz, Katari's siege continues to instill fear in the mestizo classes (Albó 1987, 379), and roadblocks attempting to sever La Paz's access to the rest of the country remain a simple, inexpensive, frequently used, and remarkably efficient political tactic. During October of 2003, food and fuel shortages were reported in La Paz as anti-Goni protests blocked the roads that bring food into the city from surrounding agricultural areas (Gotkine 2003).

Katarismo positions itself against mestizaje or state-encouraged mixing of indigenous and European cultures with the goal of eventually constructing a homogenous Latin American culture. Katarist-inspired movements point out that the goal of mestizaje is the dilution of indigenous culture (Canessa 2000, 115). Mestizaje does not eliminate culture, but blends the cultural components of the region, creating a notion of "racial harmony" that masks the truth that the region is controlled by a single group (Rowe and Schelling 1991, 18). Supporters of Morales and the MAS party have been able to capitalize on Katarist ideals to garner the support of traditional highland communities and indigenous groups whose territorial base, such as in the Cochabamba valley, is far from Katari's original highland home. 
In general, mestizaje tends to be well-accepted by the non-indigenous sector of Bolivia. As in many other parts of Latin America, the Bolivian social and economic elite who adopted European customs dominate the country's political and economic spheres, while indigenous peoples (the majority population in most parts of the country) remain disenfranchised. Some traditional indigenous communities, however, are critical of the racially and culturally mixed states that have become a demographic mainstay throughout Latin America. This is represented in a variety of ways, including the wipala (the flag of indigenous Bolivia) that shows separate distinct blocks of color symbolizing distinct culture groups. The bright colors of the wipala do not blend to create a soft rainbow effect. It is a patchwork quilt with each color square standing separate and unique. The MAS party has adopted the wipala as symbol, and political figures such as President Morales are frequently photographed with a wipala in the background.

Indigenous symbols are powerful and their use by indigenous leaders is carefully calculated. Of course, indigenous communities have been influenced by outsiders since at least the Inca conquest of the highlands. Andean women's dress, including the characteristic English bowler hat and pleated skirts worn by cholas (the women who dominate market activity in La Paz), is a classic example. Thus, indigenous communities continue to strive to remain identified as indigenous (and not mestizo) and to fight against the mestizaje processes, despite their cultures having obvious multiple influences. Radcliffe (2000) points out that the female leadership of the indigenous movement in Ecuador adopted the custom of wearing traditional Andean clothing, whereas before they wore westernized clothes. In a parallel context Wood comments that "Rigoberta Menchú adopted traditional Mayan dress as she became an international human rights leader" (2001). Adopting traditional dress, or at least rejecting the western suit and tie, can lend authenticity to an indigenous leader who hopes to remain credible with his/her constituents. Evo Morales refused to wear a suit and tie as he gained prominence in national politics. Instead, he favored a sweater that has come to symbolize his populist roots and opposition to the trappings of mestizo power.

Aymara youth living in the city of El Alto are using rap music to articulate their frustrations with a political and economic system that discriminates against them. One song by the group 'Uka Mau y Ke' examines the 2003 rebellion that started when President Sánchez de Lozada launched his proposal to export natural gas. They rap about how "bullets are being shot at the people ... we can't put up with this because the people are reclaiming their rights." It continues with "We are mobilized, arming street barricades. We are mobilized without noticing that we are killing brothers." The rap denounces "corrupt governments... with closed eyes that don't look at the reality in the society." (Dangl 2006). Aymara rappers effectively use a global youth culture to confront the cultural and economic elite who support their subordination in the global economy.

Non-governmental organizations and the working group known as the Taller de Historia Oral Andina provide a space for Aymara intellectuals to foster counter-hegemonic understandings of Andean history, political action and territorial demands (Stephenson 2002). Their goals include fostering indigenous organizational structures such as ayllus and "reconstructing and strengthening indigenous authorities" (THOA 2006). Sílvia Rivera Cusicanqui, a well-know Aymara intellectual, was a founding member of this group and played a key role in laying the ground work in the 1970s to foster indigenous pride. This organization and others have helped traditional communities to oppose neo-liberal economic policies for decades.

\section{Economic Globalization in the Lowlands}

If the goal of the contemporary radical Katarista movement in the Bolivian high- 
lands is to foster an autonomous nation separated from non-indigenous Bolivia (Sanjinés 2002), their struggle is closely watched by mestizo groups in the lowlands who also argue that they want more regional autonomy. Mestizo groups in the lowlands, in particular a group who call themselves the Camba Nation, have embraced much of the rhetoric of the highlands as they forge their own movement (Lowrey 2006).

People in the eastern lowland city of Santa Cruz, and to a lesser extent the city of Tarija, envision a country where they enjoy more freedom from a national government that seems overly concerned with the demands of the highland population. A movement of Cambas (mestizos of lowland indigenous Guaraní and European heritage) has successfully integrated their culture identity with a neoliberal economic agenda (Ballvé 2005). The Camba movement combines a historic mistrust of bureaucracy and the decisions made by the elite in the distant city of La Paz to feed the desires of the lowland population for more autonomy and control over the production and sale of the natural gas that is found in the lowlands (Lowrey 2006, Román 2005, Stearman 1985).

The indigenous groups of lowland Bolivia, part of the larger Guaraní family and known locally as the Chiquitanos, have their own rich histories (Murrieta 2005, Parejas, Alcides and Suárez Salas 1992, Ros and Combés 2003, Tomichá 2002). They are increasingly articulating demands for their traditional lands and have staged several well-publicized marches from Santa Cruz to La Paz (a march of 1,000 kilometers including gain in elevation of over 3000 meters) to draw attention to their cause (El Deber 31 October 2006).

More so than in the highlands, people of the lowlands have embraced European styles of dress and standards of beauty. In 2004, Miss Bolivia, a native of Santa Cruz, the industrial, agricultural and banking center close to large natural gas reserves, created an international scandal by commenting that

"Unfortunately, people who don't know Bolivia very much think that we are all just Indian people," adding that the image typified La Paz, which has "poor people and very short people and Indian people ... I'm from the other side of the country. We are tall and we are white people and we know English." (quoted in Bridges 2004).

Following these comments, a variety of groups including some elite-dominated institutions, called for her resignation. The young woman from Santa Cruz expressed succinctly the racial divide that separates highland and lowland Bolivia and the perception in Santa Cruz that outsiders know of only the Andes.

The November/December 2004 issue of the NACLA Report on the Americas entitled "Bolivia Fights Back" portrays the struggles in Bolivia as one of heroic indigenous resistance fighting in the highlands or in the coca-producing areas of the country. In a subsequent issue of the Report Ballvé (2005) discusses the separatist movement in the eastern lowlands but his analysis is limited to two pages. It is very likely that NACLA will continue to publish relevant articles on Bolivia and the importance of the movement in the eastern lowlands will be discussed in detail. However, the title of the 2004 issue merits scrutiny. Against who is Bolivia "fighting back"? Surely some are fighting against neoliberal reforms that further undermine the average Bolivian's capacity to provide for their families. However, pro-economic globalization policies are strongly supported in various sectors of the Bolivian population and not just by mestizos in the lowlands. El Alto has a strong manufacturing and export sector and a constituency that can be surprisingly pro-globalization (Laruta 2005). T-shirts worn by proud mestizos in the city of Santa Cruz proclaim "Yo soy Boliviano" (I am Bo- 
livian) and strengthening political movements claim to protect the rights of mestizos.

\section{Growing Dissent in the Eastern Lowlands}

Neoliberal and capitalist pressures do not come uni-directionally from outside the country. Bolivia has its fair share of home grown neoliberals and capitalists, many of whom have strong ties to the eastern, natural-gas rich, region. Portraits and biographical sketches of some of Santa Cruz's leading capitalists reveal a group of men with varied but strongly European cultural heritage (Lora 2005). Without a doubt, international business is a strong political force in Bolivia but it would not be able to survive without the commitment of Bolivians who embrace its philosophy and prescriptions. The Santa Cruz Civic Committee is well-known in Bolivia for its ties to Bolivia's business elite (Buitrago 2005). This group of elite mestizo men is energizing the eastern part of the country with rhetoric that mirrors that used effectively on the altiplano (Lowrey 2006). They appeal to a sense of regional and cultural pride that stresses their unique (nonAndean) culture.

In Bolivia, the phrase Media Luna (Half Moon) refers to the country's eastern arc of states including Santa Cruz, Chuquisaca, Tarija, Pando and Beni. The Media Luna's regional identity is organized around a shared mestizo culture that places itself in opposition to the indigenous highlands. The culture of the state of Tarija (which borders Argentina) might be decidedly different from that of the state of Pando (which is part of the Amazon region) but the people in these states affirm that they are different from people in the highlands. Although indigenous groups such as the Guaraní are found in large numbers in the region, mestizo culture dominates.

One of the prominent political groups working on behalf of this region is the Movimiento Nación Camba de Liberación (Movement for the Liberation of the Camba Nation). This movement was founded in 2001 and is based in the city of Santa Cruz. Cambas boast strong European cultural ties that bear little resemblance to those of the Aymara and Quechua speaking peoples of the highlands. Cambas argue that they provide much of the real wealth in the country, at least in terms of legal foreign exports, and resent having to share their relative wealth with the highlands (Costas 2005).

The people of Santa Cruz (and to a lesser extent Tarija and other eastern states) are now asserting themselves as a political force and challenging assumptions about their ability to rally support for their causes. The most visible manifestations of the political efforts of the people of Santa Cruz are the autonomy movement and the formulation of a Law of Hydrocarbons in 2004 with favorable terms for the eastern, natural gasproducing, states.

A town meeting brought 300,000 people into the streets of Santa Cruz on January, 28, 2005, to support autonomy. Although the real meaning of the meeting, and in fact what the people of Santa Cruz actually mean by "autonomy", has been challenged and discussed widely in the Bolivian press, the rally clearly demonstrated that mestizos in Santa Cruz can mobilize a population just as well as the indigenous leaders of the highlands (Lora 2005). As surely as indigenous communities in the highlands exert influence over political process in Bolivia through taking to the streets, mestizo groups in the lowlands can use similar means to further their own political agenda. Their movement, at its core, is pro-economic globalization. The commodity that they hope to sell in a global market is natural gas. The struggle over resources hinges on whether people support domestic consumption or export promotion.

It is difficult not to romanticize the struggles of the indigenous groups and condemn the actions of the mestizos as selfish or solely the work of transnational financial interests. This confrontation could be characterized as one of rich mestizo capitalists 
against poor indigenous farmers, but poverty and exploitation are not the sole province of highland groups. Clearly, large areas of highland Bolivia suffer from grinding intractable poverty. However, sections of the lowlands also share the same indicators. Poor nutrition and lack of access to education and medical care are still major social concerns throughout the country.

\section{Goni the Gringo: A Presidency in Two Parts}

It is not unusual in Bolivia for a president to serve two non-consecutive terms. Sometimes these two terms have decidedly different characters. Hugo Banzer, a military dictator who seized power in the 1970s, was democratically elected in 1997. Victor Paz Estenssoro served four terms as president-- the first during the famous 1952 Bolivian Revolution. He returned to the Presidency in 1985 and set the stage for policies that later took away many of the reforms of the 1952 Revolution. Gonzalo Sánchez de Lozada, also served two terms as president. However, during both terms, Goni was widely regarded as part of the international business establishment and a supporter of the interests of the mestizo class. The Wall Street Journal reported favorably on Gonzalo Sánchez de Lozada's plan to privatize state industries and commented that "the advance guard of international business is coming to the top of the Andes" (Hendrix 1995).

\section{Goni's First Term}

During Sánchez de Lozada's first term of office (1993-1997), many considered him a puppet of the United States embassy and often ridiculed him for his gringo accent and Yankee ways. Goni grew up in the United States, attended the University of Chicago, and only as an adult returned to his ancestral home, where he built a fortune in the mining business. Early in his political career, he earned a reputation for closely following IMF and World Bank recommendations including the privatization of public companies. Amid much protest, and with tremendous human cost, Bolivia privatized the national oil, telephone, electricity, mining, airline, and railway companies by the mid-1990s (Gill 2000, Kaimowitz and Thiele 1999, Kohl 2006, Schroeder 2000).

Bolivian regionalism, in its current form, was fostered by The Law of Popular Participation in the 1990s. This law was part of a comprehensive seven point agenda called the Plan de Todos (Plan for Everyone), enacted in 1993 by Sánchez de Lozada, that allowed for some decision-making at the local level along with some state revenues for local development projects (Kohl and Farthing 2006, 126). It also eased the entry of transnationals into Bolivian markets with long lasting and widespread implications (Perreault 2005, Sanabria 1999). Neoliberal reform in Bolivia is part of wider political and economic movements that, in part, are responding to transnational pressures for economic liberalization and decentralization of the government. Perrault (2005) has argued that in Bolivia, political and economic restructuring is conducted to enhance political stability and democratic participation with an eye towards encouraging foreign investment. As the autonomy movement gains strength in the eastern region of Bolivia, a strong undercurrent of the autonomy debate is the freedom to allow more independent economic decision- making, including over issues of taxation (Springer 2005).

\section{Goni's Second Term}

The Kataristas of the 1970s drew attention to United States influence over the Bolivian Government. Sílvia Rivera Cusicanqui (1991) suggests that the Kataristas used this strategy to raise national support for their movement and to help broaden their base from the altiplano to other regions. The question of Bolivian autonomy and United 
States influence in Bolivian internal affairs remains a politically charged issue. For example, it was widely reported in 2002 that after the United States' Ambassador to Bolivia condemned presidential candidate Evo Morales, public support for him throughout Bolivia dramatically increased (Ralston 2002). Morales came in second in the election, and he thanked the United States ambassador for his help.

Sánchez de Lozada, who emerged from the 2002 election as President, was Evo Morales' opposite in every way. The political protests that brought down Goni in his second term in October 2003 were the result of Katarist-inspired indigenous movements but they could not have succeeded without a broader base of support. A wide variety of events could have sparked the protests that ended Goni's presidency. For example, the legal cultivation of coca leaves has long been a cause of political turmoil and Morales had his political start as the head of the Coca Growers Union. However, it was the announcement that Goni would allow foreign companies to export natural gas that brought longsimmering tensions to a head (Kohl and Farthing 2006, 120; Orgáz García 2004, 264).

Perreault $(2006,161-162)$ identifies the formation of a National Coordinator for the Defense of Gas, led by the well-known activist Óscar Olivera as one of four principal factors that increased pressure on the Goni regime in 2002-2003. (Óscar Olivera had risen to international prominence as a leader in Cochabamba's Water War in 2000.) As mentioned previously, a key tactic used by protestors throughout Bolivia is the roadblock. Groups opposed to the terms of sale of Bolivian natural gas organized numerous successful and long-running roadblocks around the country. In September 2003, Sánchez de Lozada sent the Bolivian military to "rescue" stranded tourists (domestic and international) in the resort town of Sorata. A confrontation led to the death of six people, including an eight-year old girl (El Deber 21 September 2003). Protests and roadblocks intensified after this incident, bringing in wider support from those who disagreed with Goni's handling of the incident.

On October 12, 2003 when violence erupted again and the first protestors in the city of El Alto were killed, demonstrations against the President grew in magnitude and intensity. Within days, Goni was no longer viable as president. Fifty-three people were killed in the political disturbances. At the core of these protests, and in the eventual overthrow of Goni, is a deeply-held conviction, long articulated by the Kataristas, that the mestizo government does not take indigenous concerns, and indeed indigenous lives, seriously. After days of protest and negotiation, Goni fled to the United States.

The "Gas War," as it has been called, was not so much over the sale of natural gas, but over who would reap the most benefits from the sale. (See Perrault 2006 for a comparison of the Gas Wars to the Cochabamba Water Wars). The indigenous peoples of Bolivia have long been exploited because of their country's bountiful natural resources and were not going to sit by passively and watch it happen again. Many Bolivians were disagreed with a proposal to build a gas pipeline that would have run to the Pacific Ocean through Chile. The War of the Pacific (1879-83), when Bolivia lost its coastline to Chile, is still an important topic in Bolivia, and the notion that Chile would benefit from the sale of natural gas enraged Bolivians across a wide political spectrum (Orgáz García 2004, 264).

The popular uprising that led to the ouster of Sánchez de Lozada clearly demonstrates the broad anti-economic globalization movement has strong support at least among certain highland groups. However, Goni's resignation was complex in its meaning and a failure of political systems at a variety of scales and it would be a great simplification to claim that it was just about the sale of natural gas. The Katarist movement has been reborn in the Andes as an effective political opposition to forces broadly described as globalization and has become politically viable through the efforts of indig- 
enous leaders such as Felipe Quispe and Evo Morales. Although these two men are rivals, they both have strived to ensure that indigenous Bolivians benefit from engagement in the world economy. When Morales took office in January 2006, he did so with a rarely achieved majority in the nation election and a broad mandate from the Bolivian people.

\section{Regional Evidence of the Highland-Lowland Divide and what it means for Economic Globalization}

\section{The 2004 Natural Gas Referendum}

In the aftermath of the violence that brought down President Sánchez de Lozada, Carlos Mesa, the new or "Constitutional" President, held a referendum on natural gas. In July of 2004, the Bolivian people went to the polls. There was some confusion about whether or not voting was compulsory and nationwide the voter participation rate was around $60 \%$, which is lower than typical in Bolivia (CNE 2004). Some political groups urged their constituents to boycott the election because of the way that certain questions were worded. Labor unions, civic commitees and political parties all took stances on the referendum (Arrarás and Deheza 2005). Some groups campaigned for people to cast "blank" votes in protest (Casteño 2005). Despite low voter turn out, confusion, and a significant number of blank votes, regional patterns can be discerned from the referendum with a split between some highland and lowland departments.

Five propositions appeared on the referendum dealing with different aspects of natural gas. The referendum was long, some of the questions were complexly worded, and it is possible that many people did not understand what they were voting for. The text of the provisions and the results are shown in Table 1. Four types of results were reported for each question: invalid; blank; yes; and no. In general, the results were reported in the international press as victory for President Carlos Mesa's plan to go ahead with the development of the export sector (e. g. Benson 2004). However, even the most basic analysis of the results reveals complexity and regional divisions.

The first question asked whether the Hydrocarbon Law (No. 1689) passed during the second Sánchez de Lozada administration should be repealed — this law was viewed as being pro-transnational corporations. The answer was a resounding 'yes' with a strong majority of voters in every state. Nationwide, $77 \%$ of the valid votes supported the repeal of the law. Only 12\% voted 'no'. However, in the state of Santa Cruz over 18\% of the voters said 'no'. When one considers the large number of blank and invalid votes, $18 \%$ saying 'no' to the repeal is significant. Although this law was unpopular, it was less unpopular in the state of Santa Cruz. People in Santa Cruz stood to benefit substantially from the provisions for the export of natural gas outlined in the law. In the state of Tarija, which holds the vast majority of Bolivia's natural gas, over $80 \%$ of the votes cast were 'yes' and only $8 \%$ were 'no.' This reflects the particular political climate of Tarija and a local interpretation that the Hydrocarbon Law was not supportive enough of transnational gas interests (Casteño 2005).

The second question asked if the state should recover ownership over all hydrocarbons at the wellhead-this question approached the idea of nationalization of the natural gas supply. The question was answered 'yes' by a large majority of voters $(82 \%)$ nationwide with the smallest majority in the state of Santa Cruz $(78 \%)$. More revealing might be the percentage of 'no' votes, which could be interpreted as a rejection of nationalization. In Santa Cruz, $12 \%$ of the votes were 'no.' In the highland state of Potosí, $6 \%$ were 'no.' These results are not surprising given the disparate interests of these states. 
The third question asked if the state-oil company should be re-founded (it had previously been partially privatized). A vote of 'yes' can be interpreted as a rejection of privatization. Nationally, this received an approval of almost $78 \%$. This provision passed in every state but Cochabamba where $13 \%$ of the votes cast were blank (or protest) votes. The next smallest majority of 'yes' votes $(71 \%)$ was in Santa Cruz and Santa Cruz had a large percentage of 'no' votes (20\%). These votes show Santa Cruz's more favorable stance on privatization. In the highland state of Potosí, over $80 \%$ of the votes cast said that the state oil company should be re-founded and about $8 \%$ of the votes said 'no.' Tarija's votes are hard to interpret and probably reflect the local political dynamics (Casteño 2005).

Question four asked if people agreed with the policy of using gas to recover viable access to the sea. This question raised the issue of Bolivia's strained relationship with Chile and the potential that natural gas could be used to leverage access to the Pacific. This question is clear evidence of Bolivia's perpetual struggle to regain what they lost during the War of the Pacific. Unfortunately, the responses to this question were mixed and viewed by observers as an indication that people did not understand the question (Centellas 2004).

The fifth and final question on the referendum asked about the export of gas. Nationwide, $53 \%$ of votes supported this proposition. In the gas-rich eastern part of the country, in particular in the state of Tarija, $74 \%$ of the voters said 'yes.' Other Media Luna states, Santa Cruz (61\% 'yes'), Pando (72\% 'yes'), and Beni (68\% 'yes') demonstrated they were interested in finding an international market for natural gas. This question received its lowest approval in the state of Potosí (38\%). In the states of Oruro (44\% 'yes'), Cochabamba (49\% 'yes'), and La Paz (50\% 'yes') this question was not widely supported. The highlands, where the idea that gas should be used domestically is popular (Orgáz García 2004), voted against exporting natural gas.

Longstanding contracts already exist to export Bolivian natural gas to Argentina, and Brazil is a major investor in the Bolivian gas industry. In the lowland states these international markets are prized. In the highland states, in particular in the state of Potosí, the international sale of natural gas is viewed with suspicion. After all, Potosí is at the center of Bolivia's famous and struggling mining industry. Few people know the economic (and literal) dangers of selling natural resources to the world market like the people of Potosí. The results of this referendum, rather than provide a mandate for transnational export of gas, as was widely reported in the international press, demonstrate strong regional divisions that have deep roots and implications that reach beyond the natural gas sector. The referendum results have been used by President Morales and his supporters to justify the nationalization of the gas reserves in May of 2006 (Parenti 2006).

\section{The 2004 Municipal Elections}

Following the 2003 crises, the Bolivian political party system did not provide much hope for the resolution of conflicts over representation, natural gas, coca production and a long list of domestic issues (Zuazo 2004). Domingo (2005) comments on the fragility of Bolivian democracy and explains that Bolivia's commitment to democracy since the 
Voter Participation Rate for the 2004 Gas Referendum

\begin{tabular}{|c|c|c|c|c|c|c|c|c|c|c|}
\hline & BOL & Beni & CHQ & CBB & LPZ & ORU & Pando & SCZ & POI & TJA \\
\hline Part. & $60 \%$ & $49 \%$ & $62 \%$ & $61 \%$ & $65 \%$ & $67 \%$ & $54 \%$ & $53 \%$ & $60 \%$ & $58 \%$ \\
\hline
\end{tabular}

Provision One: Do you agree that the Hydrocarbons Law (No. 1689) approved by Gonzalo Sanchez de Lozada should be repealed?

\begin{tabular}{|c|c|c|c|c|c|c|c|c|c|c|}
\hline & BOL & Beni & CHQ & CBB & LPZ & ORU & Pando & SCZ & POI & TJA \\
\hline yes & $77 \%$ & $73 \%$ & $82 \%$ & $77 \%$ & $77 \%$ & $77 \%$ & $79 \%$ & $70 \%$ & $78 \%$ & $81 \%$ \\
\hline no & $12 \%$ & $13 \%$ & $8 \%$ & $11 \%$ & $10 \%$ & $10 \%$ & $12 \%$ & $18 \%$ & $9 \%$ & $8 \%$ \\
\hline blank & $12 \%$ & $14 \%$ & $10 \%$ & $12 \%$ & $13 \%$ & $13 \%$ & $10 \%$ & $12 \%$ & $13 \%$ & $11 \%$ \\
\hline
\end{tabular}

Provision Two: Do you agree that the state should recover ownership over all hydrocarbons at the wellhead?

\begin{tabular}{|l|c|c|c|c|c|c|c|c|c|c|}
\hline & BOL & Beni & CHQ & CBB & LPZ & ORU & Pando & SCZ & POI & TJA \\
\hline yes & $82 \%$ & $79 \%$ & $86 \%$ & $84 \%$ & $82 \%$ & $83 \%$ & $85 \%$ & $78 \%$ & $83 \%$ & $86 \%$ \\
\hline no & $8 \%$ & $8 \%$ & $5 \%$ & $7 \%$ & $7 \%$ & $6 \%$ & $7 \%$ & $12 \%$ & $6 \%$ & $5 \%$ \\
\hline blank & $11 \%$ & $14 \%$ & $9 \%$ & $10 \%$ & $12 \%$ & $11 \%$ & $9 \%$ & $11 \%$ & $12 \%$ & $10 \%$ \\
\hline
\end{tabular}

Provision Three: Do you agree that YPFB (the state-oil company) should be refounded, recovering the state's ownership of stakes held in the part-privatized oil companies, so that it can take part in all the stages of the hydrocarbon production chain?

\begin{tabular}{|c|c|c|c|c|c|c|c|c|c|c|}
\hline & BOL & Beni & CHQ & CBB & LPZ & ORU & Pando & SCZ & POI & TJA \\
\hline yes & $78 \%$ & $76 \%$ & $83 \%$ & $44 \%$ & $77 \%$ & $80 \%$ & $83 \%$ & $71 \%$ & $81 \%$ & $83 \%$ \\
\hline no & $13 \%$ & $14 \%$ & $8 \%$ & $49 \%$ & $12 \%$ & $10 \%$ & $9 \%$ & $20 \%$ & $8 \%$ & $7 \%$ \\
\hline blank & $11 \%$ & $12 \%$ & $10 \%$ & $13 \%$ & $12 \%$ & $11 \%$ & $8 \%$ & $11 \%$ & $12 \%$ & $10 \%$ \\
\hline
\end{tabular}

Provision Four: Do you agree with President Carlos Mesa's policy of using gas as a strategic resource to recover sovereign and viable access to the sea?

\begin{tabular}{|c|c|c|c|c|c|c|c|c|c|c|}
\hline & BOL & Beni & CHQ & CBB & LPZ & ORU & Pando & SCZ & POI & TJA \\
\hline yes & $47 \%$ & $61 \%$ & $48 \%$ & $44 \%$ & $46 \%$ & $41 \%$ & $66 \%$ & $49 \%$ & $33 \%$ & $68 \%$ \\
\hline no & $39 \%$ & $23 \%$ & $38 \%$ & $42 \%$ & $39 \%$ & $44 \%$ & $22 \%$ & $37 \%$ & $50 \%$ & $18 \%$ \\
\hline blank & $15 \%$ & $16 \%$ & $14 \%$ & $13 \%$ & $15 \%$ & $15 \%$ & $12 \%$ & $14 \%$ & $16 \%$ & $14 \%$ \\
\hline
\end{tabular}

Provision Five: Do you agree that Bolivia should export gas under a national policy framework that ensures supplies for Bolivians; encourages the industrialization of gas on national territory; levies taxes and/or royalties on oil companies up to $50 \%$ of the production value of oil and gas; and earmarks resources from the export and industrialization of gas mainly for education, health, roads and jobs?

\begin{tabular}{|r|c|c|c|c|c|c|c|c|c|c|}
\hline & BOL & Beni & CHQ & CBB & LPZ & ORU & Pando & SCZ & POI & TJA \\
\hline yes & $53 \%$ & $68 \%$ & $52 \%$ & $49 \%$ & $50 \%$ & $44 \%$ & $72 \%$ & $61 \%$ & $38 \%$ & $74 \%$ \\
\hline no & $33 \%$ & $17 \%$ & $34 \%$ & $38 \%$ & $35 \%$ & $40 \%$ & $16 \%$ & $26 \%$ & $46 \%$ & $12 \%$ \\
\hline blank & $14 \%$ & $15 \%$ & $14 \%$ & $13 \%$ & $15 \%$ & $14 \%$ & $12 \%$ & $14 \%$ & $16 \%$ & $13 \%$ \\
\hline
\end{tabular}

Table 1. Results of 2004 Gas Referendum by Department.

Source: Corte Nacional Electoral. 2004. http://www.cne.org.bo (Accessed 13 June, 2006). Note: These calculated percentages obviously include errors, where totals round to more than $101 \%$. They are, however, roughly the same as other results citing CNE. See Arrarás and Deheza. 2005. These small differences do not change the analysis. 
return to civilian rule in 1982 has benefited the ruling political class. Until the 2005 Presidential elections, political parties were increasingly fractured and regional, with few having significant power throughout the country.

In the 2004 municipal elections including the nine state capitals and the important highland city of El Alto, no party received the most votes in more than one city. Morales' MAS Party received the second most votes in three cities ( $\mathrm{La} \mathrm{Paz}$, El Alto and Cochabamba) and the most total votes in the country (18.5\%). The cities of La Paz, El Alto and Cochabamba share key characteristics that make the MAS party attractive, most importantly, large and politically-active indigenous populations. However, even this assumption about political allegiance should not be taken for granted. "El Alto no es... políticamente homogéneo. La cuidad de Santa Cruz tampoco." (El Alto is not politically homogeneous. Nor is the city of Santa Cruz) (Laruta 2005). In fact, the poor predominately indigenous city of El Alto is the key location for Bolivia's growing involvement in clothing exports and has showed strong support for trade ties to international markets.

\section{The 2005 Presidential Elections}

In 2005, President Carlos Mesa received stiff criticism from a wide spectrum of Bolivian society because he refused to use force to break up roadblocks. During the first week in March of 2005, passage to the international airport in El Alto was effectively cut off, stranding Bolivians and international visitors alike. The public's criticism of Mesa's handling of the crisis severely undercut his political authority. As roadblock after roadblock besieged the country, Morales emerged as a serious contender for the Presidency. Bolivians commented that they could stop the blockades by putting the blockader, Morales, in office (Ordóñez 2005).

The emergence of the MAS party and the unprecedented election of Morales as President marked a new era in Bolivian politics. Both of the parties that did well in the 2005 presidential elections were newly formed and closely identified with their presidential candidate. MAS was founded in 1997 and is closely associated with Morales. Former Bolivian President Jorge Fernando "Tuto" Quiroga Ramírez founded the rightwing Podemos organization as the vehicle for his 2005 presidential campaign. It remains unclear if either of these groups will continue to have power once their figureheads retire from politics.

Podemos, with its base in Santa Cruz, competed well against Morales' MAS Party in the 2005 elections in the eastern party of the country. Podemos and its leader Quiroga represented the interests of the mestizo class. Podemos did poorly in the highlands where the MAS Party clearly dominated (Figure 2). Not surprisingly, MAS also did well in the lowland regions associated with coca growing.

Although Podemos won, MAS did surprisingly well (33\%) in the gas-rich lowland state of Santa Cruz and in the southern state of Tarija (32\%). This is partially a sign of the deep frustration felt by many Bolivians over the protests that heated up in 2004. Some Bolivians feared that their country would never get out of the cycle of political unrest organized by MAS (Calabi 2005, Casteño 2005).

With one exception (in the northern state of the Pando), provinces in Bolivia that have experienced increased poverty in the period from 1991 to 2001 voted for MAS. Similarly, most of the provinces that voted for Podemos have seen substantial reductions in poverty over the same time period. Interestingly, provinces where people have seen both a substantial reduction in poverty and voted for MAS are in the urban areas such as El Alto, La Paz, Cochabamba and Sucre, or in rural areas that are part of Bolivia's coca growing zones, the very place that MAS and Morales got their start. 


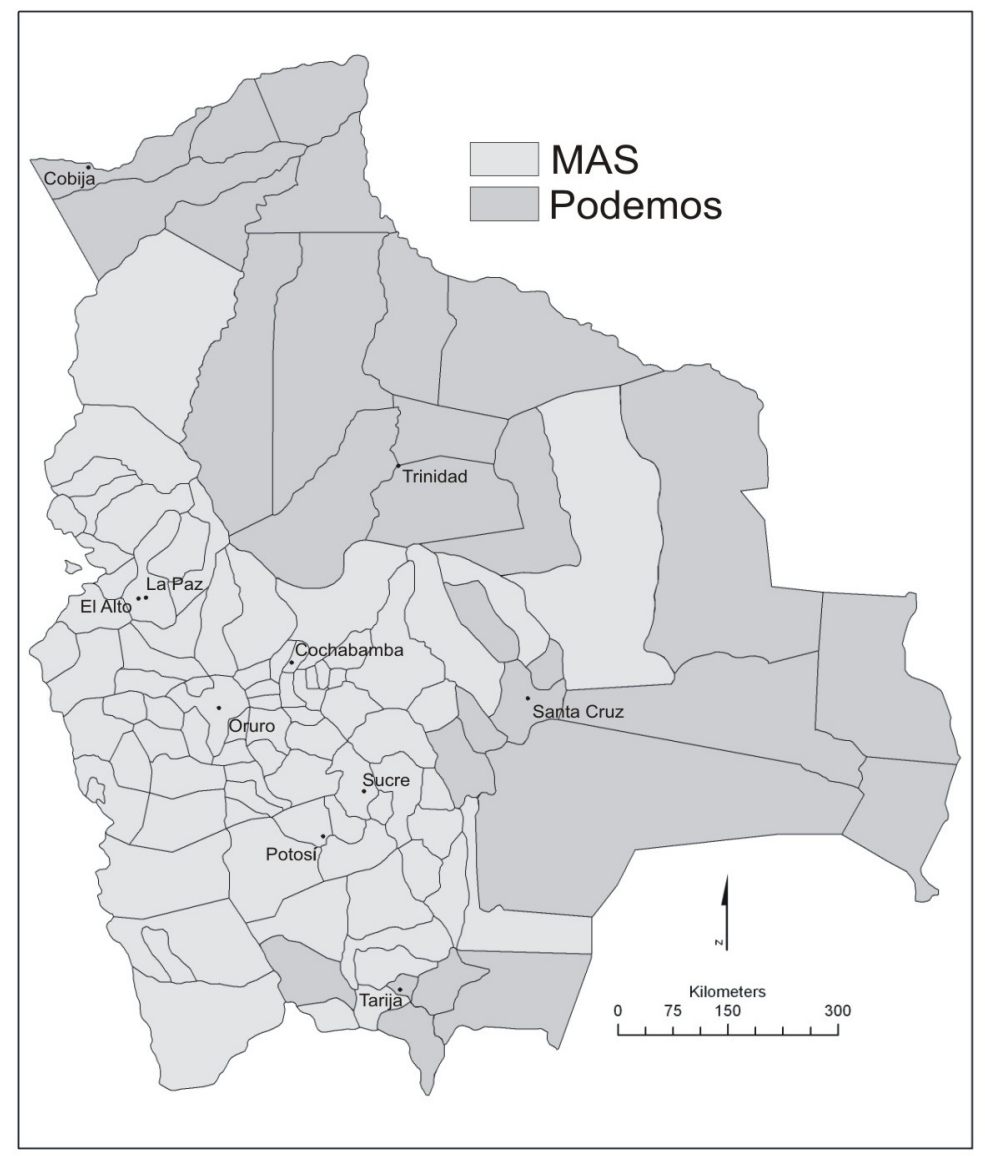

Figure 2. Party with the Most Votes in the 2005 Presidential Election. Source: CNE (Corte Nacional Electoral). 2005. http:/ /www.cne.org.bo (13 June, 2006).

\section{Conclusions}

Much has been made in the international press over the election of Evo Morales (see Lerager 2006). Morales as been depicted as a radical left-wing ideologue, or alternatively, as a savior to the indigenous poor of the hemisphere. In Bolivia, he is under pressure from indigenous leaders such as Felipe Quispe to deliver on his promised reforms. The nationalization of the natural gas fields on May $1^{\text {st }} 2006$ was, in part, a response to his radical critics who were criticizing him for his failure to act on some of his campaign promises.

Nash's analysis of globalization or "glocalization" in Chiapas, Mexico, points to the larger context that resource conflicts play as indigenous groups contest globalization. Morales' nationalization of the natural gas fields did more than assert state control over a critical natural resource. It signaled to the world (and to his political rivals) that he would push forward with a broader anti-neo-liberal economic agenda and markedly improve the quality of life of Bolivia's indigenous majority. He vowed to use the country's resources in a way that favored increasing domestic consumption over export and take seriously 
the state's responsibilities to the poor.

Perhaps surprising to those who live outside Bolivia, Morales enjoyed high approval ratings right after his election. After he nationalized Bolivia's natural gas fields in May 2006, his approval rating dropped from a previous high of $75 \%$ to $68 \%$. ( $L a$ Rąón 2006). In August 2006, his approval rating was $81 \%$, and it has since slipped and fluctuates as domestic and international events impact the country (Program on International Policy Attitudes 2006). However broad his personal popularity, he faces serious obstacles as he attempts to govern the country and he is a long way from resolving Bolivia's underlying regional divisions. Among the most important of these is a growing gap between rich and poor and diverging visions of what it means to be a Bolivian in the $21^{\text {st }}$ Century.

Keeling (2004) notes the trauma to Latin American societies from the "growing polarization of society" caused by globalization. The debate over economic globalization is not an abstract theoretical concept to many in Bolivia. It is a "glocalized" impact. People know if they are better or worse off than before. Significantly, if they follow the national news or talk to travelers, they have a sense for how different regions of the country are faring, as well. When highland indigenous populations vote for Morales and the MAS party they are voting for a change in their economic well-being. When lowland mestizo populations support Podemos they are hoping for more economic independence and growth. These two regions in the country have different agendas because they are impacted differently by engagement in the global economy.

Keeling (2004) comments that globalization can exacerbate conflicting socio-cultural identities. Powerful political movements may have drawn their base of support from Katarista groups based on the altiplano, but the anti-economic globalization movement has implications far beyond the highlands. Sánchez de Lozado, with his strong US backing, was a lightning rod for what is widely perceived as United States hegemony in Bolivian (and Latin American) affairs. Goni was uniquely ill equipped to negotiate the opposition that developed over the sale of natural gas. Political groups such as Morales' MAS party, with its strong indigenous identity, succeeded in winning the 2005 election because it reached beyond its initial core group of coca growers. Morales positioned himself as the leader of Bolivia's oppressed indigenous majority and opposed the state at every turn. However, the Morales presidency is confronted by opposition from the right and from the left and is in a difficult relationship with the United States, especially because of his friendship with Hugo Chávez of Venezuela.

These disparate movements, indigenous communities in the highlands and mestizos in the lowlands, are both largely empowered by their sense of place. A geography of globalization exists at a number of scales within Bolivia. Regional pride (which frequently overlaps with ethnic self identification) is a strong force in Bolivia. People are quick to identify themselves as being from a particular part of the country and all regions have their stereotyped personality traits. Both indigenous and mestizo groups stress their connections to the land and their rights to the resources within it. People in the lowlands argue that the riches of their land (in this case, natural gas) are their patrimony, much like the richness of the soil around Lake Titicaca. If the people of the altiplano have rights to their potato fields, why don't people of the lowlands have rights to their gas fields (Casteño 2005)?

Geographers have become deeply engaged in issues concerning globalization. The term "glocalization" draws attention to the importance and complexity of local places in these global processes. Our research should highlight the spatial realities, such as regional disparities that globalization exacerbates. Bolivia remains divided along ethnic and spatial lines. Bolivia has always been a multi-ethnic country with strong geographic 
forces dividing it. These divisions seem only to be growing under the promise of great wealth for some Bolivians from the sale of natural gas and the pressures of economic globalization. As key sectors of the Bolivian population struggle against an integration into the global economy that puts the demands of a global market ahead of the needs of a local population, others embrace globalization as the only rational approach to improving standards of living in, at least, their region of the country.

It remains to be seen how Evo Morales will negotiate this tension. Recently, Bolivians such as Román (2005) have begun discussing the forging of a new national identity that combines characteristics of highland and lowland populations. Morales' Vice President, Alvaro García Linera has written about the importance of establishing a truly multi-cultural nation and democratic government that allows for meaningful community rights based on traditional Andean practices. (García Linera, 2005). Solutions to Bolivia's regional and cultural divides may emerge from these and other Bolivian intellectuals.

The mestizo class in the lowlands is not going to disappear. They retain considerable power and strong international connections. The indigenous populations of the highlands will not quietly assimilate. They have struggled against European control for over 500 years and now that Bolivia has elected an indigenous president, they might finally find a voice in the halls of government. The complexity of Bolivia's engagement in the global economy and its strong regional characteristics will provide fruitful research opportunities for geographers for the foreseeable future.

\section{Acknowledgements}

Research conducted during 2005 was supported by a University Research Grant and Offcampus Scholarly Assignment provided by Appalachian State University. I am in debt to Annie Bryant and Stephanie Smith for their contributions to this project.

\section{References}

Albó, X. 1987. From MNRistas to Kataristas to Katari, in S. J. Stern (ed.) Resistance, Rebellion, and Consciousness in the Andean Peasant World, 18 th to 20 Centuries, pp. 379-419. Madison, WI: The University of Wisconsin Press.

Arrarás, A. and G. Deheza. 2005. Referéndum del Gas en Bolivia 2004: Mucho Más Que un Referéndum. Revista de Ciencia Politica 25(2): 161-172.

Ballvé, T. 2005. Bolivia's Separatist Movement. NACLA Report on the Americas 38(5): 1617.

Benson, D. 2004. Bolivian Vote to Export Gas in Referendum Aimed at Quelling Unrest. The Associated Press, July 19, 2004, http://web.lexis-nexis.com/universe/document? $\mathrm{m}=\mathrm{b} 5 \mathrm{e} 0 \mathrm{ded} 1 \mathrm{c} 2446$ (7 November, 2006).

Bridges, T. 2004. Bolivian Beauty Queens Highlight Nation's Racial, Regional Differences. The Miami Herald (FL), 28 July, 2004, 8A.

Buitrago, M. 2005. The History of the Comité Pro Santa Cruz. MABB, 10 February, 2005 http://mabb.blogspot.com/2005/02/history-of-comite-pro-santa-cruz (31 October, 2006).

Calabi, A. 2005. Interview by author, Tomatitas, Bolivia, 15 February, 2005. 
Canessa, A. 2000. Contesting Hybridity: Evangelistas and Kataristas in Highland Bolivia. Journal of Latin American Studies 32(1): 115-143.

Casteño, J. 2005. Interview by author, Tarija, Bolivia. 3 April, 2005.

Centellas, M. 2004. Referendum News, Ciao! musings of a rationalist urban digital cowboy, 26 May 2004, http://www.centellas.org/miguel/archives/000846.html

(15 February, 2005).

CNE (Corte Nacional Electoral). 2004. http://www.cne.org.bo (13 June, 2006).

Costas, R. 2005. Head of Santa Cruz Civic Committee in Speech Given at the Autonomy Rally in Santa Cruz, Bolivia. Broadcast on Bolivian National Television. 25 January, 2005.

Crabtree, J., G. Duff and J. Pearce. 1987. The Great Tin Crash: Bolivia and the World Tin Market. London: Latin American Bureau.

Dangl, B. 2006. Rapping in Aymara, Wiretap: Ideas and Action for a New Generation. 20 September, 2006, http://www.wiretapmag.org/stories/41902.html (19 October, 2006).

Delgado, P. G. 1994. Ethnic Politics and the Popular Movement. In S. Jonas and E. J. McCaughan (eds.) Latin America Faces the Twenty-First Century: Reconstructing a Social Justice Agenda, pp. 77-88. Boulder, CO: Westview Press.

Domingo, P. 2005. Democracy and New Social Forces in Bolivia. Social Forces 83(4): $1727-$ 1744.

Dunkerley, J. 1984. Rebellion in the Veins: Political Struggle in Bolivia, 1952-82. London: Verso Books.

Edelman, M. 2005. Bringing the Moral Economy Back into the Study of $21^{\text {st }}$ Century Transnational Peasant Movements. American Anthropologist 107(3): 331-345.

ElDeber. 2003. Violencia en el Altiplano, seis muertos. El Deber Santa Cruz, Bolivia. Digital Edition, 21 September, 2003, http://www.eldeber.com.bo/anteriores/20030921/nacional3.html (13 February, 2007).

2006. Indígenas del Oriente Marchan a La Paz por Modificación de la Ley INRA. Santa Cruz, Bolivia. Digital Edition, 31 October, 2006, http://www.eldeber.com. bo/2006/20061031/al23.html (8 February, 2007).

García Linera, A. 2003. Professor of Sociology and Political Science at Universidad Mayor de San Andrés (and later Vice President of Bolivia). Lecture on Globalization and Resistance in Andean Bolivia, GHY 3531. La Paz, Bolivia. 15 May, 2003.

García Linera, A. 2005. Estado Multinacional: Una Propuesta Democrática y Pluralista para la Extinción de la Exclusión de las Naciones Indias. La Paz, Bolivia: Malatesta. 
Gill, L. 2000. Teetering on the Rim: Global Restructuring, Daily Life, and the Armed Retreat of the Bolivian State. New York: Columbia University Press.

Gotkine, E. “Bolivia Clashes Kill Five.” BBC News. (UK Version) 13 October, 2003. http://news.bbc.co.uk/2/hi/americas/3186116.stm (16 March, 2007).

Hendrix, S. 1995. “The Americas: A Capital Idea in Bolivia." The Wall Street Journal. (Eastern Edition) 22 September, A15.

INE (Instituto Nacional de Estadística de Bolivia). 2001. Censo Nacional de Población y Vivienda 2001. Bolivia: Mapa de Pobreza.http://www.ine.gov.bo/PDF/PUBLICACIONES/Censo_2001/Pobreza/PBolivia.pdf (16 June, 2006).

Kaimowitz, D. and Thiele, G. 1999. The Effects of Structural Adjustment on Deforestation and Forest Degradation in Lowland Bolivia. World Development 27 (3): 505-521.

Keeling, D. J. 2004. Latin American Development and the Globalization Imperative: New Directions, Familiar Crises. Journal of Latin American Geography 3(1): 1-21.

Kohl, B. 2006. Challenges to Neoliberal Hegemony in Bolivia. Antipode 38(2): 304-326.

Kohl, B. and Farthing, L. 2006. Impasse in Bolivia: Neoliberal Hegemony and Popular Resistance. New York: Zed Book.

La Razón. 2006. Baja la Aprobación a la Gestión de Morales. La Razón La Paz, Bolivia, Digital Edition, 31 July, 2006,http://laRazón.glradio.com/versiones/20060731_005619/ nota_247_314762.htm (7 November, 2006).

Langer, E. 2003. Contemporary Indigenous Movements in Latin America. Wilmington, DE: Scholarly Resources Inc.

Laruta, C. H. 2005. Quoted in F. Molina, Un Mapa de la Actitud Política de los Bolivianos: ¿Existen las Mayorías Silenciosas? Pulso Semanario 286, 25 February-3 March: 14.

Lerager, J. 2006. Commentary: Report on Bolivia's Elections. Latin American Perspectives 33(2):141-144.

Liberato, A. S., C. Pomeroy, and D. Fennell. 2006. Well-Being Outcomes in Bolivia: Accounting for the Effects of Ethnicity and Regional Location. Social Indicators Research 76: $233-262$.

Lora, M. 2005. Banqueros, Terratenientes y Dueños de Medios Los Capitanes del Comando Camba. Juguete Rabioso 4(122): 8-10.

Lowrey, K. 2006. Bolivia Multiétnico y Pluricultural, Ten Years Later. Latin American and Caribbean Ethnic Studies 1(1): 63-84.

Mallon, F. E. 1992. Indigenous Communities, Political Cultures, and the State in Latin America, 1780-1990. Journal of Latin American Studies 24: 35-53. 
Murrieta, R. 2005. Landscapes of Power and Identity: Comparative Histories in the Sonoran Desert and the Forests of Amazonia from Colony to Republic. Durham, NC: Duke University Press.

NACLA (The North American Congress on Latin America). 2004. Bolivia Fights Back. NACLA Report on the Americas 38(3): 14-41.

Nash, J. C. 1979. We Eat the Mines and the Mines Eat Us. New York: Columbia University Press.

York: Routledge.

2001. Mayan Voices: The Quest for Autonomy in an Age of Globalization. New

Ordóñez, G. 2005. Denuncian Racismo en Los Tiempos de Cochabamba. El Juguete Rabioso 5(126): 2.

Orgáz García, M. 2004. La Guerra del Gas: Nación versus Estado Transnacional en Bolivia. La Paz: C\&C Editores.

Orozco Ramírez, S. 2005. Trayectoria Política e Ideológica: Historia del Movimiento al Socialismo (MAS). Barataria 1(2): 16-22.

Parejas, J., Alcides J., and Suárez Salas, V. 1992. Chiquitos: Historia de una Utopía. Santa Cruz, Bolivia: Cordecruz.

Parenti, C. 2006. Letter from Bolivia: Morales Moves. The Nation. 282(24): 20-22.

Perreault, T. 2005. State Restructuring and the Scale Politics of Rural Water Governance in Bolivia. Environment \& Planning A 37(2): 263-284.

2006. From the Guerra del Agua to the Guerra del Gas: Resource Governance, Popular Protest and Social Justice in Bolivia. Antipode 38(1): 150-172.

Program on International Policy Attitudes. 2006. Presidents of Bolivia, Argentina Get Highest Approval Ratings in Latin America. World Public Opinion 31 August, 2006. http://www.worldpublicopinion.org/pipa/articles (9 November, 2006).

Quispe, F.H. 2003. Oppressed but Not Defeated, in E. Langer (ed.) Contemporary Indigenous Movements in Latin America, pp. 205-209. Wilmington, DE: Scholarly Resources.

Radcliffe, S. 2000. Entangling Resistance, Ethnicity, Gender and Nation in Ecuador. In J. Sharp, P. Routledge, C. Philo and R. Paddison (eds.) Entanglements of Power: Geographies of Domination/Resistance, pp. 164-181. New York: Routledge.

Ralston, E. 2002. Evo Morales and Opposition to the US in Bolivia. ZNET Daily Commentaries 14 July, 2002. http://www.zmag.org/sustainers/content/2002 07/14ralston.cfm (10 November, 2006).

Rivera Cusicanqui, S. 1991. Aymara Past, Aymara Future. NACLA Report on the Americas 25(3): 18-23. 
Roca, J. L. 1999. Fisonomía del Regionalismo Boliviano, 2nd ed. La Paz, Bolivia: Centro de Información para el Desarrollo.

Román, A. H. 2005. Cambas y Collas: Los Paradigmas de una Nueva Nación. Santa Cruz, Bolivia: Gráfica Sirena.

Ros, J. I. and I. Combés. 2003. Los Indigenas Olvidados: Los Guarani-Chiriguanos Urbanos y Peri-urbanos en Santa Cruz de la Sierra. La Paz, Bolivia: Fundación PIEB.

Rowe, W. and V. Schelling. 1991. Memory and Modernity: Popular Culture in Latin America. New York: Verso.

Sanabria, H. 1999. Consolidating states, restructuring economies, and confronting workers and peasants: the antinomies of Bolivian neoliberalism. Comparative Studies in Society and History 41(3): 535-562.

Sanjinés, J. C. 2002. Mestizaje Upside Down: Subaltern Knowledges and the Known. Nepantla: Views from the South 3(1): 39-60.

Schroeder, K. 1998. Urban Squatters as Agricultural Migrants: The Case of Tarija, Bolivia. South Eastern Latin Americanist XLI (3/4): 33-43.

2000. Spatial Constraints on Women's Work in Tarija, Bolivia. The Geographical Review 90(2): 191-205.

Scott, J. C. 1976. The Moral Economy of the Peasant. New Haven, CT: Yale University Press.

Serulnikov, S. 2003. Subverting Colonial Authority: Challenges to Spanish Rule in the EighteenthCentury Southern Andes. Durham, NC: Duke University Press.

Springer, N. 2005. Bolivia: A Situational Analysis. A Written Report Commissioned by the United Nations High Commission for Refugees, Protection Information Section http://www.ilw.com/articles/2005,0629-bolivia.pdf (26 October, 2006).

Stearman, A.M. 1985. Camba and Kolla: Migration and Development in Santa Cruz, Bolivia. Orlando, FL: University of Central Florida Press.

Stephenson, M. 2002. Forging an Indigenous Counterpublic Sphere: The Taller de Historia Oral in Bolivia. Latin American Research Review 37(2): 99-118.

THOA (Taller de Historia Oral Andina). 2006. Qué es el THOA. Taller de Historia Oral Andina http://www.aymaranet.org/thoaenglish.html (2 February, 2006).

Thomson, S. 2002. We Alone Will Rule: Native Andean Politics in the Age of Insurgency. Madison, WI: University of Wisconsin Press.

Tomichá, R. C. 2002. La Primera Evangelización en las Reducciones de Chiquitos, Bolivia, 1691 1767.Cochabamba, Bolivia: Editorial Verbo Divino. 
Wood. C. A. 2001. Authorizing Gender and Development "Third World Women," Native Informants, and Speaking Nearby. Nepantla: Views from South 2(3): 429-447.

Yashar, D. J. 1998. Contesting Citizenship: Indigenous Movements and Democracy in Latin America. Comparative Politics 31(1): 23-42.

Zuazo, A. 2004. Bolivia Municipal Election Marked by the Emergence of New Groups. Associated Press, 3 December, 2004. http://web.lexisnexis.com/universe/document? $\mathrm{m}=0 \mathrm{a} 8 \mathrm{f} 44 \mathrm{bbcb} 7 \mathrm{~d}$ (26 October, 2006). 